\title{
IMPLEMENTATION OF A LOCAL CULTURE BASED SCIENTIFIC APPROACH TO IMPROVE YOUR CREATIVE THINKING SKILLS IN BASIC TEACHER EDUCATION STUDENTS
}

\author{
Ali Armadi ${ }^{1 *}$, Sihabuddin $^{2}$ \\ ${ }^{* 1}$ Prodi PGSD, STKIP PGRI Sumenep, Jawa Timur \\ ${ }^{2}$ Prodi PPKn, STKIP PGRI Sumenep, Jawa Timur \\ aliarmadi@stkippgrisumenep.ac.id \\ sihabuddin@stkippgrisumenep.ac.id
}

DOI: https://doi.org/10.21107/Widyagogik/v8i2. 8530

Received September 12, 2020; Revised October 13, 2020; Accepted November 05, 2020

\section{Abstract}

Based on the fact that happened to the PGSD STKIP PGRI Sumenep students, many students still tended to be silent, their ideas were very textual, so taking notes was a necessity in student activities. Besides, students still lack creative thinking. This is because students are too focused on the material so that the learning process tends to be passive. One example is when students make presentations, students still stick to the lecturers in the class. Thus, there needs to be an increase in creative thinking in PGSD STKIP PGRI Sumenep students. The purpose of this research is to describe the improvement of the creative thinking skills of students in the PGSD STKIP PGRI Sumenep Study Program through a scientific approach. The test results in cycle II have obtained scores above the average, this is because the attention of students in lecturing activities given by the lecturer has been able to understand and understand the material given so that students' creative thinking abilities have reached the target. The percentage of completeness of 35 students who initially got $71 \%$ increased to $88 \%$, while the observation of creative thinking students who initially got a $72 \%$ increased in cycle II to $80 \%$. So, in this study, the improvement of students' creative thinking was successfully carried out in cycle II after getting the targeted value.

Keywords : Implementation, Scientific, Creative Thinking. 
13 Implementation of A Local Culture Based Scientific Approach to Improve Your Creative Thinking Skills in Basic Teacher Education Students

Ali Armadi, Sihabuddin

\section{Introduction}

Universities must be able to print and produce educators who can adapt to members of society, and have academic skills, to develop science civilly and culturally. Efforts to improve the quality of education continue to be carried out through the improvement of educational facilities, improving the quality of educators, improving the quality of the curriculum, and also the need for opportunities to obtain education, Galuh \& Indra, (in Yeni 2017: 186). Similarly, universities must ensure their students become educators who are ready to dive into the world of education and able to become professional educators by mastering the prevailing system and curriculum as well as the latest. Besides, every educator is required to be a creative educator, this is because of the demands of the current curriculum. Educators and Education Practitioners realize that many factors influence the success of students in the learning process of teaching in schools, (Armadi 2018: 186).

Based on the reality in the field during the Citizenship Education course process, there are still many PGSD students who tend to be silent, their ideas are very textual, and take a lot of notes, so taking notes is a necessity in student activities. Besides, students still lack creative thinking. This is because students are too focused on the material so that the learning process tends to be passive. One example is when students make presentations, students only deliver material in a textual and monotonous manner and do not ask and answer questions.

The background of the study is no more than 500 words containing the background and problems to be examined, the specific purpose, and urgency of the research. In this section, it is necessary to explain the description of specific specifications related to the material development scheme contextually. Because the learning that occurs in the classroom only centered on lecturers that can be said to use discussion methods. Meanwhile, the other students only become listeners and do not give opinions or ideas that can be rising the atmosphere of the classroom to be active and creative.

Based on the above problems the author seeks to solve the problem by doing a different implementation than before. The author tries to apply a scientific approach based on the local culture that exists on Madura island with the dance culture mask gethak on the course of Citizenship Education as an effort. Because it is believed that between the scientific approach and the local culture will be a good collaboration in the lecture process, especially in the learning of Citizenship Education which is also thick with attitude and culture in Indonesia. The scientific approach has been implemented in elementary schools in the 2013 curriculum. According to Fadhilaturrahmi (2017:110), a scientific approach is a student-centered approach so that students actively construct concepts, laws, or principles through the stages of observing, formulating problems, filing or formulating hypotheses, collecting data with various techniques, analyzing data, drawing conclusions and communicating concepts, laws or principles found. Thus, this approach is used to stimulate each learning to form students to be active. Lecturers here only act as facilitators and motivators, students as student centers in this scientific 
study. So as a prospective educator trained to be active and creative during the course process of citizenship education. The application of a scientific approach is expected so that students can have more creative thinking skills. According to Filsame (in Fauziah 2011:100), Creative thinking is a thought process that has the characteristics of smoothness, flexibility, authenticity or originality, and detailing or elaboration. On the other hand, Edward de Bono (in Euis 2015:5) this creative thinking skill allows humans to see various perspectives to solve problems in certain situations. In creative thinking, students can be known if the indicators in Creative Thinking are implemented. But in creative thinking certainly have indicators that not all students have.

The implementation of a local culture-based scientific approach is very important for educators, especially in students. Therefore, the application of the scientific approach is combined with local wisdom culture. The excavation of local wisdom is very important to the formation of Indonesian child characters. These values include a) spiritual values, b) disciplined and appreciative character values, c) ethical and moral values, d) social care values, e) tolerance and friendly peace love values, (Ridwan 2016, 2017a, 2017b, 2018a and 2018b). On the other hand, local wisdom has a profound effect on learning. One of the local wisdom in Sumenep is gethak mask dance. Gethak mask dance is one of the characteristics of traditional art owned by Pamekasan regency, and Madura in general. The principle of gethak mask dance is a dance that has a strong, rigid, open-minded and straight character philosophy in uncovering every problem the character is considered to portray the character of Madura people in general. This kind of learning approach is expected to facilitate students to master the subject matter to improve their learning outcomes, through local culture. According to Ridwan (2017), Sumenep is known for its city of culture and Madura has a variety of traditional cultures and various types of tourism that are very diverse. It would be perfect if the scientific approach was combined with the dance culture of gethak mask in reminding the creative thinking skills of students of STKIP PGRI Sumenep. Because in its application, it will be very easy for lecturers and students in the ongoing lecture process and make the lecture more active and creative in discussing.

The research objective was to describe the application of a scientific approach based on local culture in improving the creative thinking skills of students of the PGSD Study Program at STKIP PGRI Sumenep. And to describe the increase in the creative thinking of PGSD students of STKIP PGRI Sumenep through a scientific approach based on local culture. The benefits of this research are expected to be able to make a positive contribution to the implementation of a scientific approach based on local culture in improving creative thinking skills in students of the PGSD study program, STKIP PGRI Sumenep. The output of this research is the publication of scientific articles in the form of accredited national journals ranked 1-6. To anticipate the extent of the problems discussed, the authors define the problems so that this research becomes more focused.

The term limitation contained in the formulation of the title of this study is the use of scientific methods in students asking that learning in lectures be better, and understanding and student activeness in lectures are better to achieve the intended 
15 Implementation of A Local Culture Based Scientific Approach to Improve Your Creative Thinking Skills in Basic Teacher Education Students

Ali Armadi, Sihabuddin

competencies. On the other hand, this scientific method is used as an illustration of previous learning, so that students are more active in learning (Abduh, 2017: 307). Meanwhile, according to Armadi, (2018: 54), the scientific method is a strategy carried out in learning activities based on a problem, observing, asking questions, gathering information, and applying all material carried out by students. Creative thinking is a thinking activity to increase the purity (originality) and sharpness of understanding (insight) and developed into things previously unknown, namely something new from previously existing ideas by someone (Ismayati, 2013: 46). Meanwhile, Sternberg and Renzulli (in Firdaus, 2016: 227) state that creative thinking is a certain type of gift and is an important component of gifts. "Local wisdom is the ability to absorb foreign cultures that come selectively, meaning that it is adapted to the local atmosphere and conditions" (Atmojo in Agus 2014: 212). Creative thinking is a particular type of gift and is an important component of gifts. "Local wisdom is the ability to absorb foreign cultures that come selectively, meaning that it is adapted to the local atmosphere and conditions" (Atmojo in Agus 2014: 212). Creative thinking is a particular type of gift and is an important component of gifts. "Local wisdom is the ability to absorb foreign cultures that come selectively, meaning that it is adapted to the local atmosphere and conditions" (Atmojo in Agus 2014: 212).

\section{Method}

This type of research is using PTK (Classroom Action Research). According to Arikunto (2007: 3), which states that classroom action research is an improvement activity carried out in a problem that occurs in the learning process in the classroom. This research is a classroom action research that refers to the model of Kemmis and Taggart (in Arikunto 2014: 16) which is based on planning, action or observation, and reflection. The researcher here acts as a teacher or lecturer. 


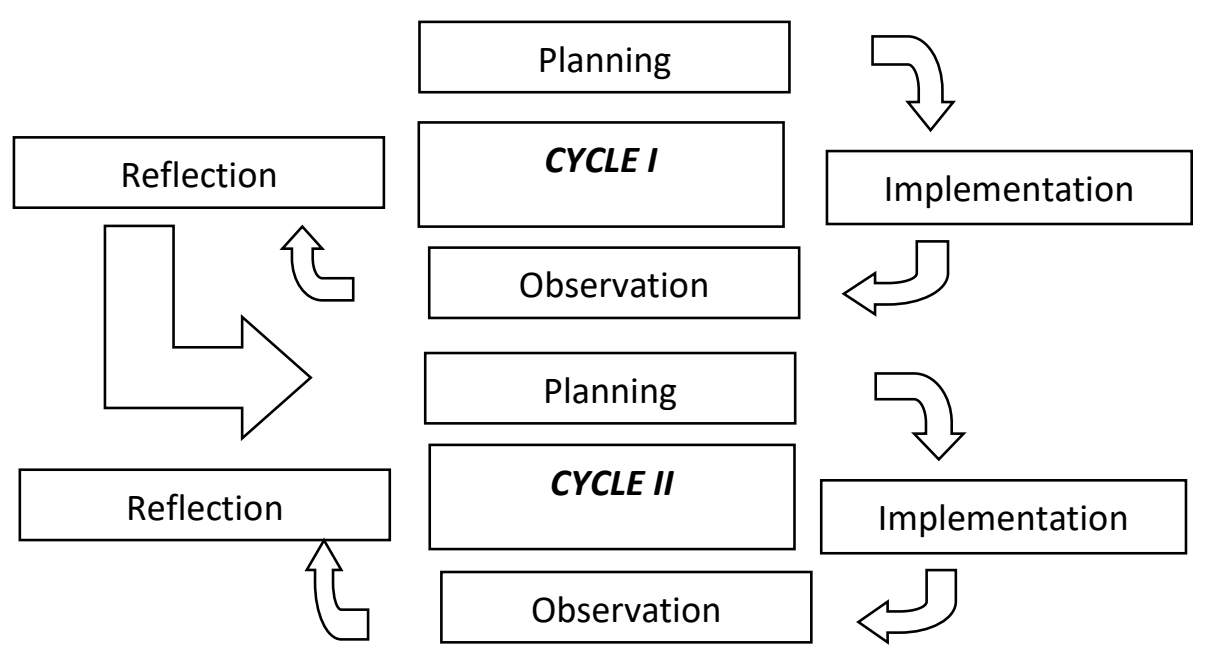

Figure 1 Flow of Classroom Action Research Model Kemmis and MC. Taggart

The subject of this research is the second-semester student of the PGSD Study Program at STKIP PGRI Sumenep who takes the Citizenship Education course. There are 35 students, consisting of (14) male and (21) female. While the data collection techniques needed in the study were tests, observation, and documentation. The test used in this research is a subjective test, which is in the form of an essay. This test is to measure students' creative thinking skills. Prepared according to the Citizenship Education Subject. The observation technique used in this research is systematic observation using guidelines as an observation instrument to describe the process of improving the creative thinking skills of the second-semester students of the PGSD STKIP PGRI Sumenep Study Program who teach civic education courses. Documentation is part of a way to collect important documents in research. The documentation in this research is in the form of lesson plans, observation instruments, and photos of activities. As stated by Arikunto, (2013: 274) that documentation is looking for data about things or variables in the form of notes, transcripts, books, newspapers, magazines, inscriptions, meeting minutes, agendas, and so on. Then the research instrument in this study used tests and the Creative Thinking Observation Sheet Format. After all the data collected, it is necessary to immediately process the data or analyze the data until the value reaches the target, this classroom action research is quantitative, so the method used in this research uses quantitative descriptive data analysis methods.

\section{Result and Discussion}

The explanation of the results of the action in each cycle is the result of the action based on the formulation of the existing problem, at this stage, the researcher will explain briefly the actions and processes during the actions that have been taken from the initial observation stage. The entire action cycle consists of several stages, namely action planning, implementation or observation, and reflection. The following are the initial conditions from the results of the observations that found a problem. Based on 
17 Implementation of A Local Culture Based Scientific Approach to Improve Your Creative Thinking Skills in Basic Teacher Education Students

Ali Armadi, Sihabuddin

the reality in the field during the Citizenship Education course process, there are still many PGSD students who tend to be silent, their ideas are very textual, and take a lot of notes, so taking notes is a necessity in student activities. Besides, students still lack creative thinking. This is because students are too focused on the material so that the learning process tends to be passive. One example is when students make presentations, students only deliver material in a textual and monotonous manner and there is no enrichment or follow-up from the lecturers. That way, the researcher prepares everything to fix the problems of student creative thinking skills that have occurred. The following are the results of the implementation of the action from cycle I to cycle II.

\section{Research Results Cycle I}

The results of the first cycle research, there are several stages, namely, action planning, observation or observation, and reflection. At the planning stage, the researcher determines how to improve creative thinking skills in second-semester students in the civic education course using the scientific approach. Then the researchers compiled a Learning Implementation Plan (RPP). Then the researcher prepares everything needed in research such as learning media that is under the material being taught. Compile an observation format and a scale for increasing creative thinking skills.

The action is carried out under the learning plan that has been made, which refers to the RPP that has been compiled by the researcher. During the classroom action activity, the researcher is also tasked with observing changes in behavior and attitudes that occur in students. The data on the results of the action were obtained from observations of students and the results of creative thinking skills filled in by students after the teaching and learning process took place. After the implementation of class actions in cycle I have been completed, a test is carried out using creative thinking questions with essay test questions adjusted to the civic education material in cycle I, there are 10 essay tests where the essay test questions contain indicators of creative thinking skills including fluent thinking, thinking detailing, flexibility thinking, original thinking. These creative thinking indicators proposed by Guilford and Torance (in Rusyna 2014: 120), there are four characteristics of creative thinking, namely: originality (originality), elaboration (elaboration), fluency (fluency), and flexibility (flexibility). Originality refers to the uniqueness of each response. Originality is indicated by an unusual, unique, and rare response. Elaboration is a bridge when someone will convey creative ideas. Elaboration is indicated by the number of additions and details that can be made to some simple stimulus to be complex. Fluency is the ability to generate multiple ideas. This is one of the strongest indicators of creative thinking. flexibility is the ability to see things directly from multiple perspectives. The four characteristics of creative thinking (fluency, flexibility, originality, and elaboration) enable individuals to generate creative ideas and solve various problems. The results of the data in the 
research cycle I above am used to making it easier to find the percentage of student completeness in civic education courses.

As the result, In the first cycle, there were still some students who could not answer the questions correctly and did not achieve the above scores in creative thinking skills. Of the 35 students, only 25 students completed, this shows that the indicator of success has not yet reached $75 \%$. During the first cycle, the researcher also observed the creative thinking skills of students individually using the creative thinking observation sheet provided. Only a few students were able to think creatively in the first cycle of creative thinking skills. This was obtained from the lecture process that took place in improving creative thinking through student creative thinking sheets, namely getting 71\%. During the first cycle, the researcher also observed the creative thinking skills of students individually using the creative thinking observation sheet provided. The results of the percentage of students' creative thinking are as follows:

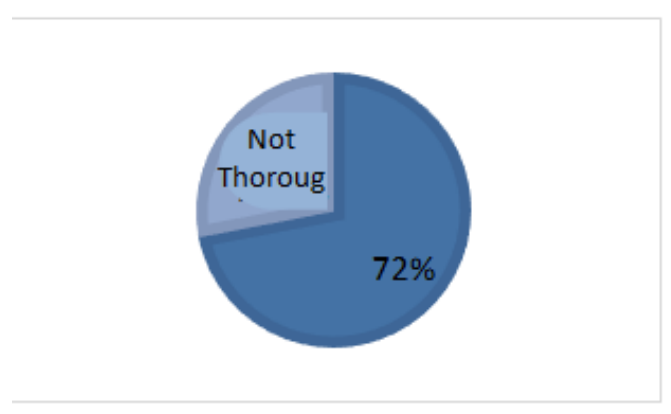

Figure 2. Observation of Creative Thinking Cycle I

It is known from the observation of students' creative thinking skills in cycle I only a few students can think creatively. This can be seen from the results of creative thinking skills through the student's creative thinking sheet which is getting $72 \%$. The result of the cycle I in the course of Citizenship Education obtained data in the form of test results and observations of creative thinking through the implementation of the scientific approach based on local culture in students of semester II Program PGSD STKIP PGRI Sumenep namely, the test results in cycle I are still below average, this is due to the lack of attention of students in the lecture activities given by lecturers so that the creative thinking ability of students still does not reach the target of $75 \%$. Then the observation of creative thinking of students is still not good, this is due to the lack of activeness of students in lecture activities in citizenship education courses.

\section{Results of Cycle II Research}

The action in cycle II is to improve the previous cycle. Researchers see or learn things that have been done in cycle I, and correct mistakes that have occurred to achieve an increase in students' creative thinking skills using the implementation of a scientific approach based on local culture. Classroom action research was carried out in 
19 Implementation of A Local Culture Based Scientific Approach to Improve Your Creative Thinking Skills in Basic Teacher Education Students

Ali Armadi, Sihabuddin

the same way, namely at STKIP PGRI Sumenep on semester II PGSD students. The research planning stage in the second cycle was made based on the reference from the results of the reflection in cycle I which became the consideration for the implementation of the action in cycle II. Planning in cycle II as a follow-up to the research carried out in cycle I, all the deficiencies in cycle I are fixed and fixed to improve the quality and ability of students to think creatively. There are three stages in cycle II, namely planning, action and observation, and reflection. In the second cycle, the students were able to do the questions correctly and had reached a value above the indicators of creative thinking skills. It can be seen from 35 students that 31 students completed, this shows that the indicators of success have reached even more than $75 \%$, namely getting $88 \%$. At the time of the implementation of cycle II, students have been able to fully contribute in the class, for example when the percentage of the class atmosphere has become active without having to stick to the lecturer, each student can ask or give his opinion so that this also affects the results of the student's creative thinking test. During the second cycle, the researcher also observed the creative thinking skills of students individually using the creative thinking observation sheet provided. The results of the percentage of student creative thinking in cycle II are as follows:

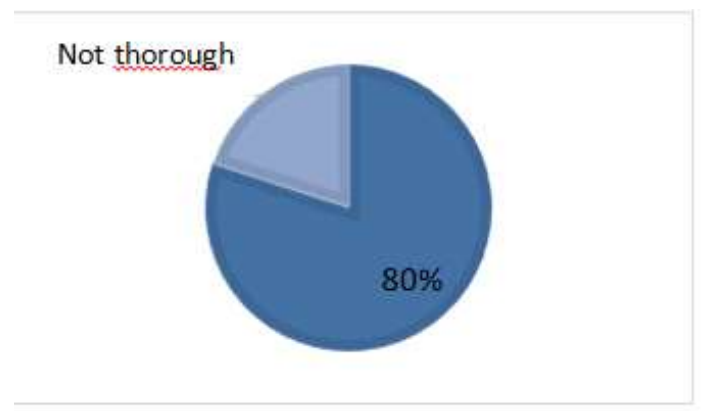

Figure 3. Observation of Creative Thinking Cycle II

It is known from the results of observations of students' creative thinking skills in the second cycle that only a few students were able to think creatively. This can be seen from the results of the ability to think creatively through students' creative thinking sheets which include predetermined indicators, namely getting $80 \%$. Then, the test results in cycle I have obtained scores above the average, this is because all students can work on the questions that have been given based on indicators of creative thinking which are used as benchmarks for each answer given by students, as well as student attention in activities lectures were given by the lecturer have been able to understand and understand the material given, so that students' creative thinking abilities have reached the target. In the results of the essay test given to students in cycle I increased in cycle II, the percentage of completeness that initially got $71 \%$ increased to $88 \%$, while the observation of students' creative thinking who initially got $72 \%$ increased in cycle II to $80 \%$. Then the results of student creative thinking observations have increased, this is due to the lecturers' emphasis on student activeness in lecturing activities in civic 
education courses so that the lecture process in the classroom takes place actively and creatively. The results of the observation of student creative thinking in the first cycle got a $59 \%$ increase in the second cycle to $85 \%$. From the two cycles above, it can be seen that there is an increase in creative thinking skills in students of the PGSD STKIP PGRI Sumenep study program from cycle I to cycle II. This shows that students' creative thinking skills have been successfully carried out in cycle II. The results of the assessment were obtained from a test in the form of an essay given to students to answer questions with creative thinking skills, where each student's answer has a weight/score in the achievement of students' creative thinking indicators. The result is that the average value in the second cycle is 80 . The calculation of the average test score and observation of creative thinking is by adding up the scores obtained by all students divided by the number of students. Then get the average test results and creative observations.

The following are the test results between the results of the action research cycle I and cycle II:

Table 1. Data on Cycle I and Cycle II Test

\begin{tabular}{|c|c|c|c|}
\hline No. & STUDENT'S NAME & CYCLE I & CYCLE II \\
\hline 1 & Student 1 & 78 & 78 \\
\hline 2 & Student 2 & 76 & 74 \\
\hline 3 & Student 3 & 64 & 84 \\
\hline 4 & Student 4 & 78 & 76 \\
\hline 5 & Student 5 & 74 & 78 \\
\hline 6 & Student 6 & 78 & 80 \\
\hline 7 & Student 7 & 62 & 88 \\
\hline 8 & Student 8 & 78 & 80 \\
\hline 9 & Student 9 & 80 & 78 \\
\hline 10 & Student 10 & 74 & 90 \\
\hline 11 & Student 11 & 84 & 76 \\
\hline 12 & Student 12 & 76 & 78 \\
\hline 13 & Student 13 & 78 & 74 \\
\hline 14 & Student 14 & 80 & 84 \\
\hline 15 & Student 15 & 78 & 76 \\
\hline 16 & Student 16 & 80 & 78 \\
\hline 17 & Student 17 & 88 & 80 \\
\hline 18 & Student 18 & 54 & 88 \\
\hline 19 & Student 19 & 80 & 80 \\
\hline 20 & Student 20 & 88 & 78 \\
\hline 21 & Student 21 & 62 & 90 \\
\hline 22 & Student 22 & 78 & 76 \\
\hline 23 & Student 23 & 54 & 78 \\
\hline 24 & Student 24 & 78 & 74 \\
\hline 25 & Student 25 & 88 & 84 \\
\hline 26 & Student 26 & 64 & 76 \\
\hline 27 & Student 27 & 46 & 78 \\
\hline
\end{tabular}


21 Implementation of A Local Culture Based Scientific Approach to Improve Your Creative Thinking Skills in Basic Teacher Education Students

Ali Armadi, Sihabuddin

\begin{tabular}{|c|c|c|c|}
\hline 28 & Student 28 & 78 & 80 \\
\hline 29 & Student 29 & 88 & 88 \\
\hline 30 & Student 30 & 80 & 80 \\
\hline 31 & Student 31 & 78 & 78 \\
\hline 32 & Student 32 & 88 & 90 \\
\hline 33 & Student 33 & 80 & 80 \\
\hline 34 & Student 34 & 64 & 64 \\
\hline 35 & Student 35 & 78 & 90 \\
\hline \multicolumn{2}{|c|}{ Average } & 72 & 80 \\
\hline & Percentage & $71 \%$ & $88 \%$ \\
\hline
\end{tabular}

Could be seen from the table above that the ability of student test results has increased in cycle II. From the data obtained by researchers, there is an increase that occurs from cycle I to cycle II. It can be seen from the table above that the percentage in the first cycle of Citizenship Education courses is $71 \%$, while the results of the actions in the second cycle have increased to $88 \%$. The average value of the first cycle was 72 . Because they had not obtained the maximum desired result, the researcher continued and researched the next cycle. In the second cycle, the average score of students in each Citizenship Education course increased and obtained an average score of 80 . For this reason, in this study, there was no need for a further cycle to be carried out because this study was successful and successful in cycle II. Therefore.

\section{Conclusion}

It can be concluded that using a scientific approach based on local culture can improve creative thinking skills towards students in semester II of PGSD STKIP PGRI Sumenep. This can be seen from the improvement of the creative thinking skills of students of PGSD STKIP PGRI Sumenep Program through a scientific approach based on local culture successfully carried out in cycle II. This research was conducted in two cycles that occurred in the improvement between cycle I and cycle II of all students namely, 35 students. Where in cycle I the percentage of completeness obtained in citizenship education courses gets $71 \%$ and the average score is 72 . While in cycle II there was an increase in essays given to students, with completed by $88 \%$ with an average score of 80 .

Suggestions are given by several parties, namely, the lecturer should pay more attention to the approach and planning as well as possible before the course is carried out so that the lecture process runs smoothly and well. Lecture activities in the classroom should require the involvement of lecturers and students to be more active in improving students' creative thinking skills.classical learning completeness in cycle II obtained a percentage of $92.3 \%$. This acquisition is included in the very high category. 


\section{References}

Abduh, M. (2017). Interaksi Pada Pendekatan Saintifik (Kajian Teori Scaffolding). Seminar Nasional - Pendidikan PGSD UMS \& HDPGSDI Wilayah Jawa, 978-60270471-2. https://www.researchgate.net/publication/322489030

Ali, A. (2017). Pendekatan Scientific Dalam Pembelajaran Tematik Terpadu di SD. Jurnal Autentik Vol: 1 No: 1 55-67, 2548-9119. Autentic.stkippgrisumenep.ac.id

Ali,A., Yeni, P. (2018). Pembelajaran Terpadu Tipe Webbed Berbasis Budaya Lokal Untuk Meningkatkan Hasil Belajar Siswa Kelas IV Sekolah Dasar. Premiere Educandum, Jurnal Pendidikan Dasar dan Pembelajaran, 2528-5173 Vol: 8 (2) 185-195. Universitas PGRI Madiun. https://www.researchgate.net/publication/329757321

Agung, S. (2012). Budaya Lokal Dalam Perspektif Agama: Legitimasi Hukum Adat ('Urf) Dalam Islam. ESENSIA, XIII No. 2 Juli. https://www.researchgate.net/publication/322548058

Alo, L. (2003). Makna Budaya dalam Komunikasi Antar Budaya. Jakarta: LkiS Pelangi Aksara.

Daryanto. (2014). Pendekatan Pemebelajaran Saintifik Kurikulum. Yogyakarta: Gava Media.

Dhaevatun, F. (2005). Perkembangan Tari Topeng Gethak Di Kabupaten Pamekasan Pada Tahun 1980-. e-Jurnal Pendidikan Sejarah Universitas Negeri Surabaya. $\begin{array}{lllll}\text { Volume } & 3 & \text { Nomor } & 3 & \text { Oktober. }\end{array}$ https://jurnalmahasiswa.unesa.ac.id/index.php/avatara/article/view/1297 9.

Efendi, A. (2014). Implementasi Budaya Kearifan Lokal Pada Masyarakat Adat Kampung Kuta Sebagai Sumber Pembelajaran IPS. Sosio Didaktika - 1, No.2. http://journal.uinjkt.ac.id/index.php/SOSIO-FITK/article/view/1263

Fadhilaturahmi. (2017). Penerapan Pendekatan Saintifik Untuk Meningkatkan Kemampuan Komunikasi Matematik Peserta Didik Di Sekolah Dasar. EduHumaniora: Jurnal Pendidikan Dasar, 2085-1243 Vol. 9. No.2. https://ejournal.upi.edu/index.php/eduhumaniora/article/view/7078

Firdaus. (2016). Meningkatkan kemampuan berpikir kreatif matematis siswa SMA melalui pembelajaran open ended pada materi SLDV. Teori, penelitian, dan pengembangan, 2502-4711X. Volume: 1 Nomor: 2. http://journal.um.ac.id/index.php/jptpp/article/view/6127

Hasbullah. (2008). Dasar-dasar IImu Pendidikan. Jakarta: PT. Raja Grafindo Persada.

Istinah, E. (2013). Meningkatkan Kemampuan Berpikir Kritis dan Kreatif Matematik dengan Pendekatan Model Elicting Activities (Meas) pada siswa Infinity. 
23 Implementation of A Local Culture Based Scientific Approach to Improve Your Creative Thinking Skills in Basic Teacher Education Students

Ali Armadi, Sihabuddin

Jurnal ilmiah program studi matematika STKIP Siliwangi Bandung, Volume $2 \quad$ Nomor $1 . \quad$ http://www.ejournal.stkipsiliwangi.ac.id/index.php/infinity/article/view/23/22

Iswarso, S. (2016). Kreatif. Yogyakarta: Relasi Inti Media.

Kunandar. (2012). Penelitian Tindakan Kelas. Jakarta: Rajawali Pers.

Muhadi. (2011). Penelitian tindakan kelas. Yogyakarta: shira media.

Munandar, U. (2014). Kreatifitas \& Keberbakatan Srategi Mewujudkan Potensi Kreatif \& Bakat. Jakarta: Penerbit Gramedia Pustaka Utama

Musfiqon. (2015). Pendekatan Pembelajaran Saintifik. Sidoarjo: Nizamia Learning Center.

Nurlaela, L. (2015). Strategi Belajar Berpikir Kreatif. Yogyakarta: Ombak.

Riduwan. (2011). Belajar Mudah Penelitian. Bandung: Alfabeta

Ridwan, M. (2014). Kurikulum (2013). dan Pendidikan Nilai Kearifan Lokal di Sekolah Dasar. In Prosiding Seminar Nasional Pendidikan tema Implementasi Kurikulum 2013 dan Problematikanya, Pascasarjana UNESA Tahun 2014 (pp. 102-108).

Ridwan, M. (2016). Pendidikan Karakter Berbasis Permainan Tradisional Siswa Sekolah Dasar di Sumenep Madura. Prosiding Seminar Nasional Prodi PGSD dan Prodi BK FKIP UAD. ISBN: 978-602-70296-8-2

Ridwan, M. and Wahdian, A., (2017). Structure, Function, and Value The Tradition of Oral Literature in Sumenep Madura. ISLLAC: Journal of Intensive Studies on Language, Literature, Art, and Culture, 1(1), pp.252-273.

Ridwan, M., (2017). Tradisi Nyanyian Anak Terhadap Pembentukan Karakter Anak Usia Sekolah Dasar. Sekolah Dasar: Kajian Teori dan Praktik Pendidikan, 26(1), pp.49-61.

Ridwan, M., (2018). Learning of local environmental wisdom in the oral literature of Madurese traditional song in sumenep. ISCE: Journal of Innovative Studies on Character and Education, 2(1), pp.93-103.

Ridwan, M., (2018). Literature Syi'ir MaduraAs A Legenskap Of Strengthening Characters In Elementary School. ISCE: Journal of Innovative Studies on Character and Education, 2(2), pp.332-339.

Rusyna, A. (2014). Belajar Berpikir. Yogyakarta: Ombak Dua.

Sugiyono. (2010). Metode penelitian kualitatif kuantitatif dan R\&D. Bandung: alfabeta Suharsimi, A,dkk. (2014). Penelitian Tindakan Kelas. Jakarta: PT. Bumi Aksara 
Suparno,Geri.A,dkk. (2018). Mempertahankan Eksistensi Budaya Lokal Nusantara Ditengah Arus Globalisasi Melalui Pelestarian Tradisi Gawai Dayak Sintang. $\begin{array}{lllll}\text { Jurnal Pekan, } & \text { Vol. } & 3 & \text { No. } & 1 .\end{array}$ http://jurnal.stkippersada.ac.id/jurnal/index.php/PEKAN/article/view/144 Suparto. (2004). Mengenal Kesenian Tradisional Pamekasan. Naskah Pribadi.

T.O. Ihroni. (2000). Antropologi dan Hukum. Jakarta: Yayasan Obor Indonesia.

Yanuar Bagas, A. (2017). Revitalisasi Peran Budaya Lokal Dalam Materi Pembelajaran Bahasa Indonesia Bagi Penutur Asing (Bipa). The 1st Education and Language International Conference Proceedings Center for International Language Development of Unissula, $\quad$ p.915 $\quad$ - $\quad 920$. http://jurnal.unissula.ac.id/index.php/ELIC/article/view/1318 